\title{
CONDIÇÕES DE OCORRÊNCIA DAS ÁGUAS SUBTERRÂNEAS E DO POTENCIAL PRODUTIVO DOS SISTEMAS AQÜÍFEROS NA REGIÃO METROPOLITANA DE CAMPINAS - SP
}

\author{
Sueli YOSHINAGA-PEREIRA \\ Annkarin Aurelia Kimmelmann e SILVA
}

RESUMO

O presente trabalho é uma avaliação hidrogeológica executada na Região Metropolitana de Campinas, região centro-este do Estado de São Paulo. Esta área pertence a região de conturbação da Bacia do Piracicaba e Capivari, região de ocorrência dos grandes sistemas aqüíferos Cristalino e Tubarão e, localmente, os diabásios. Nesse estudo, 1711 poços foram cadastrados, onde 1008 apresentaram dados hidrodinâmicos, 1217 possuem perfil geológico e 10 são resultados de testes de bombeamento. Os resultados mostraram a forte influência de estruturas tectônicas, falhas normais e densidades de fraturas para a produtividade de poços no Sistema Aqüífero Cristalino. Os movimentos neotectônicos também podem estar relacionados à produtividade dos poços. A presença do manto de alteração pode caracterizar um aqüífero de porosidade primária cobrindo esse sistema aqüífero regional. A capacidade específica mostrou valor mediano de $0,1 \mathrm{~m}^{3} / \mathrm{h} / \mathrm{m}$ e vazão de $5,2 \mathrm{~m}^{3} / \mathrm{h}$. A transmissividade de seis poços foram: 0,$32 ; 0,13 ; 0,14 ; 0,18 ; 6,85 ; 0,29 \mathrm{e} 1,18 \mathrm{~m}^{2} / \mathrm{dia}$. Os sedimentos arenosos de subsuperfície e os mais altos valores de espessura de sedimentos foram os parâmetros relacionados a uma melhor produção dos poços no Sistema Aqüífero Tubarão. O valor mediano da capacidade específica e vazão são $0,11 \mathrm{~m}^{2} /$ dia e $6,0 \mathrm{~m}^{3} / \mathrm{h}$, respectivamente. Os poços em diabásios apresentaram baixos valores de capacidade específica $(0,06 \mathrm{~m} / \mathrm{h} / \mathrm{m})$ e sua produtividade está relacionada a presença de fraturas. A produtividade de poços que explotam mais do que um aqüífero (poços mistos), pode estar relacionada a espessura saturada e aos limites mais profundos entre unidades aqüíferas. As zonas de produtividade podem estar relacionadas aos blocos estruturais com movimentos neotectônicos, encontrados na área de estudo. O valor mediano de capacidade específica e vazão são $0,07 \mathrm{~m} / \mathrm{h} / \mathrm{m} \mathrm{e} 4,8 \mathrm{~m}^{3} / \mathrm{h}$, respectivamente. Os poços que explotam o Aqǘfero Diabásio e Tubarão mostraram os mais altos valores de produtividade. As transmissividades foram determinadas em três poços, obtendo os seguintes valores: 0,$113 ; 2,77$ e 0,71 $\mathrm{m}^{2} /$ dia.

\section{ABSTRACT}

The present work is a hydrogeologic assessment of the Campinas Metropolitan Region, central-eastern portion of the state of São Paulo. The study area belongs to the urbanized region of the Piracicaba and Capivari watersheds, where occur two regional aquifer systems, the crystalline and the Tubarão aquifers; locally, diabases also occur. 1711 wells were registered, of which 1008 hydrodynamic data were available (e.g. static and dynamic levels and yield); 1217 have geological logs, and 10 pumping test results.The results showed the strong influence of tectonic structures, normal faults and fracture density on the productivity of wells in the crystalline rocks. Productivity may be also related to the neotectonic movements. In the weathering materials an aquifer of primary porosity develops. Specific capacity showed a median value of $0.1 \mathrm{~m}^{3} / \mathrm{h} / \mathrm{m}$ and yield of $5.2 \mathrm{~m}^{3} / \mathrm{h}$. The transmissivities of six wells were 0.32 , $0.13,0.14,0.18,6.85,0.29$ and $1.18 \mathrm{~m}^{2} /$ day. The underground sandy sediments and the high values of sediment thickness were parameters related to better production of wells in the Tubarão Aquifer System. The median value of specific capacity and yield are $0.11 \mathrm{~m} / \mathrm{h} / \mathrm{m}$ and $6.0 \mathrm{~m}^{3} / \mathrm{h}$, respectively. Wells in diabases presented low values of specific capacity $(0.06$ $\mathrm{m}^{3} / \mathrm{h} / \mathrm{m}$ ); their productivity is related to fractures. The productivity of wells that exploit more than one aquifer system may be related to the saturated thickness of the sedimentary aquifer and to the deeper limits between aquifer units. Production zones may be related to structural 
blocks with neotectonic movements, encountered in the study area. The median value of specific capacity and yield are $0.07 \mathrm{~m}^{3} / \mathrm{h} / \mathrm{m}$ and $4.8 \mathrm{~m}^{3} / \mathrm{h}$, respectively. Wells that exploited both the diabases and the Tubarão Aquifer System showed the highest values of productivity. Transmissivities were determined in three wells, obtaining the values of $0.113,2.77$ and 0.71 $\mathrm{m}^{2} /$ day.

\section{INTRODUÇÃO}

O presente trabalho consiste na execução de uma avaliação hidrogeológica, executada na Região Metropolitana de Campinas, pertencente à área de conurbação da Bacia do Piracicaba e Capivari, onde ocorrem os grandes sistemas aqüíferos regionais, Cristalino e Tubarão e, subordinadamente, os diabásios.

Nessa área, o trabalho pretende ampliar o conhecimento desses sistemas aqüíferos e suas inter-relações, por meio da caracterização da geometria dos aqüíferos, hidrodinâmica e potencial produtivo.

\section{MATERIAIS E MÉTODOS}

O método de estudo consistiu no cumprimento de etapas de trabalho, comuns ao desenvolvimento de projetos de pesquisa, como: revisão da bibliografia referente à área de estudo; trabalhos de campo, tratamento e análise das informações levantadas.

\subsection{Levantamento das informações existentes}

As informações utilizadas para a execução do trabalho em questão, consistiram no levantamento e análise da bibliografia referente à caracterização do meio físico, sócio-econômico e uso e ocupação do solo da área de estudo, no sentido de se obter um primeiro diagnóstico. Os assuntos abordados foram relativos a evolução sócio-econômica, geologia, geomorfologia e clima, geotecnia, pedologia, hidrogeologia.

Os mapas geológico e geomorfológico usados nesse estudo foram compilados com base na bibliografia existente, na escala 1.100 .000 (IG, 1993; IG, 1995; SOUZA FILHO, 1986; BASEI, CAMPOS NETO, BERGMAN \& FIGUEIREDO, 1986; VLACH, 1993; CPRM, 1974; DAEE/UNESP, 1982; IPT, 1981 e PIRES NETO, 1996).

As informações hidrogeológicas levantadas foram de nível regional e local, citando-se as seguintes referências: BERTACHINI (1987); CAMPOS (1993); CAVALCANTE (1990); DAEE (1981); DINIZ (1990); DIOGO et al.
(1984); GROUNDWATER-HIDROGEOLOGIA E ENGENHARIA (1984); INSTITUTO GEOLÓGICO (1993 e 1995); LOPES (1984 e 1994); STEVAUX et al. (1987).

O cadastramento de poços tubulares profundos foi desenvolvido em projetos do Instituto Geológico (IG, 1993; IG, 1995) e consistiu no cumprimento de duas etapas distintas de trabalho: primeiramente, executou-se o cadastramento de poços com visitas ao Departamento de Águas e Energia Elétrica, aos Serviços Municipais de Água e Esgoto (SAEE e SAMAE) e às empresas de perfuração de poços tubulares profundos. $\mathrm{Na}$ segunda etapa, os trabalhos de campo foram executados no sentido de complementar e locar os poços cadastrados, assim como efetuar novos levantamentos de poços, utilizando mapas na escala 1:10.000 (IG, 1993; 1995). Nos municípios de Campinas, Jaguariúna, Holambra, Cosmópolis, Paulínia e Nova Odessa, o cadastramento de campo foi executado de forma completa. Em Americana, Sumaré e Hortolândia, os dados já estavam organizados nas prefeituras (IG, 1993; 1995). Nos municípios de Santa Bárbara d'Oeste, Engenheiro Coelho, Valinhos, Vinhedo, Monte Mor, Pedreira, Santo Antonio da Posse, utilizou-se os dados executado pelo DAEE (1981).

As informações obtidas foram colocadas em fichas e inseridas no banco de dados:SIPO, do Instituto Geológico, que foi desenvolvido pelo pesquisador Geraldo Hideo Oda, em linguagem DBASE Plus e Clipper.

$\mathrm{Na}$ área de estudo, foram cadastrados 1711 poços tubulares profundos, onde 1008 possuem dados hidrodinâmicos (leia-se nível estático, nível dinâmico e vazão), 1217 com perfis geológicos, 1684 com informações sobre o uso da água subterrânea, e 10 com testes de bombeamento.

\subsection{Processamento e análise das informações}

Os estudos desenvolvidos neste trabalho abordam diferentes temas, os quais tiveram procedimentos variados quanto ao tratamento de dados específicos para cada tipo de análise executada. Porém, as interpretações dos resultados foram integradas, onde a análise de cada tema 
corroborou, reforçou ou apresentou os resultados com conclusões inéditas.

No tratamento das informações e elaboração final dos resultados, foram utilizados os softwares Excel, Word, Surfer, AutoCAD e DBASE Plus. Para o cálculo da transmissividade dos testes de bombeamento existentes, foi utilizado o cálculo de Cooper-Jacob pelo programa TESTBOMB 1.0 (Clark, cópia em disquete).

Os procedimentos de análise para cada tema desenvolvido são descritos a seguir:

- Geologia e Geomorfologia - uso de bibliografia e mapeamentos existentes nas diversas escalas e compilação cartográfica na escala $1: 100.000$.

- Geometria dos Sistemas aQÜIferos base geológica, bibliografia existente e inventário de poços tubulares profundos (especificamente, dados dos perfis geológicos dos poços) são usados para a caracterização tridimensional dos aqüiferos, com a confecção de mapas de isoespessuras de sedimentos (arenitos e siltitos/argilitos), contorno estrutural do embasamento cristalino e espessura do manto de alteração e ocorrências de diabásios em subsuperfície.

- Circulação das ÁguAs SUBTERRÂNEAS - é avaliada com base nos dados de nível estático dos poços tubulares profundos cadastrados e na topografia do terreno. As curvas eqüipotenciais são delineadas considerando-se os dados de nível estático e assim, as áreas de recarga e descarga locais são determinadas.

- Caracterização hidrodinâmica e ANÁLISE DA PRODUTIVIDADE - os parâmetros utilizados para a caracterização hidrodinâmica foram: capacidade específica $\left(\mathrm{m}^{3} / \mathrm{h} / \mathrm{m}\right)$; transmissividade $\left(\mathrm{m}^{2} / \mathrm{dia}\right)$; vazão dos poços. Foram avaliados os sistemas aqüíferos Tubarão, Cristalino, Diabásios e os poços que explotam mais de um aqüífero (mistos). A produtividade dos poços foi relacionada com as litologias e estruturas, determinando-se seus fatores condicionantes. A análise de parâmetros hidrodinâmicos para a caracterização das condições de ocorrência das águas subterrâneas, nos sistemas aqüíferos locais, teve tratamento estatístico dos dados de capacidade específica, determinandose a mediana de cada sistema aqüífero.

No aqüífero sedimentar, as medianas de capacidade específica de poços com perfis que possuem arenito (em porcentagem) foram correlacionados. O mapa de isovalores da porcentagem de arenito nos perfis de poços foi sobreposto a um mapa de capacidades específicas, no intuito de determinar as zonas com maior potencialidade de produção.
A caracterização da produtividade dos poços, em função da litologia sedimentar aflorante também é avaliada, bem como as feições geomórficas, como vales e grandes lineamentos determinados pela rede de drenagem obtidas em mapas topográficos na escala de $1.50 .000 \mathrm{com}$ imagem satélite, na escala 1:100.000.

No aqüífero diabásio, os procedimentos de análise hidrodinâmica consistiram em caracterizar, inicialmente, a mediana da capacidade específica dos poços, e verificar a importância da feição vale e dos lineamentos de fraturas na produtividade.

No aqüífero cristalino, o método utilizado é o mesmo aplicado para o aqüífero diabásio, incluindo a análise estatística de capacidade específica por litologias e a distribuição das freqüências dos valores médios dos poços, em relação a direção dos lineamentos de fratura. A espacialização e o zoneamento dessas produtividades são baseadas essencialmente na geologia estrutural da área.

Os poços mistos são analisados estatisticamente e separadamente, pois as produtividades podem estar correlacionadas justamente com a combinação dos vários sistemas aqüíferos ou de seus contatos. Alguns procedimentos indicados para a análise do aqüífero sedimentar, cristalino e diabásio foram adotados, dependendo da ocorrência destas formações nos perfis geológicos em poços tubulares.

As tendências de distribuição da produtividade são determinadas e analisadas sob o enfoque das litologias predominantes, da espessura do pacote sedimentar e das grandes estruturações existentes na área.

\section{3 ÁREA DE ESTUDO-REGIÃO METROPOLITANA DE CAMPINAS}

\subsection{Situação geográfica}

A área de estudo situa-se a cerca de $150 \mathrm{~km}$ da capital do estado, entre os paralelos $22^{\circ} 25^{\prime} \mathrm{S}$ e $23^{\circ} 15^{\prime} \mathrm{S}$ e meridianos $46^{0} 30^{\prime} \mathrm{W}$ e $47^{0} 35^{\prime} \mathrm{W}$. Os municípios abrangidos pelo estudo compõem a Região Metropolitana de Campinas (Americana, Artur Nogueira, Campinas, Cosmópolis, Engenheiro Coelho, Holambra, Hortolândia, Indaiatuba, Jaguariúna, Monte Mor, Nova Odessa, Paulínia, Pedreira, Santa Bárbara d'Oeste, Santo Antonio da Posse, Sumaré, Valinhos e Vinhedo). Esta região é denominada pela EMPLASA (1993) como Área de Metropolização da Região de Campinas e ainda envolve municípios em início de processo de ocupação urbana e de características rurais, como Cosmópolis e Holambra (FIGURA 1). 
Em termos de gerenciamento de recursos hídricos, a área localiza-se dentro da Unidade de Gerenciamento (UGRHI) 5, composta das bacias hidrográficas de Piracicaba, Capivari e Jundiaí.

A Rodovia dos Bandeirantes (SP-348), Via Anhanguera (SP-330), Rodovia Dom Pedro I (SP-065) e Via Marechal Rondom (SP-300), são as principais vias de acesso à região Metropolitana de Campinas.

\subsection{Situação socioeconômica}

A Região Metropolitana aqui considerada possui uma população de 1.802 .022 habitantes, que corresponde a $5,77 \%$ da população total do Estado de São Paulo (EMPLASA, 1993). Segundo o Núcleo de Estudos Populacionais (NEPO-UNICAMP, 1992 apud EMPLASA, 1993), há um "corredor de circulação da população" que se estende pela via Anhanguera e Bandeirantes, com início de expansão deste corredor em direção à Campinas-Sorocaba.

Campinas, o município mais antigo, foi o centro irradiador da ocupação humana e de certa forma responsável pela criação de novos municípios da região. As emancipações dos municípios mais antigos datam do século passado. Os restantes são bem jovens, com ‘daciss menores de cem anos. As emancipações recentes de municípios podem ter como causa principal o alto crescimento populacional e socioeconômico das regiões circunvizinhas de Campinas.

A Região Metropolitana de Campinas sempre possuiu importância econômica e função social, por se situar em local estratégico de caminho para o interior de São Paulo e Minas Gerais, favorecendo a participação de processos históricos de atividades econômicas predominantes, como a cultura do café e a industrialização, com a conseqüente expansão urbana.

O processo de crescimento na região é acompanhado da queda da qualidade de vida, com o aumento de favelas e de periferias pobres em Campinas e municípios de entorno, explicada pela intensa industrialização, que também é responsável pelo alto grau de urbanização. Os municípios de Sumaré, Nova Odessa, Americana e Santa Bárbara d'Oeste, situados no eixo da via Anhanguera foram os responsáveis pelas maiores taxas de crescimento populacional registradas, causadas pelo próprio processo de industrialização da região. Este crescimento populacional é responsável em grande parte pelo processo migratório, especificamente nos municípios de Sumaré, Santa Bárbara d'Oeste, Nova Odessa, Artur Nogueira, Campinas e Vinhedo.

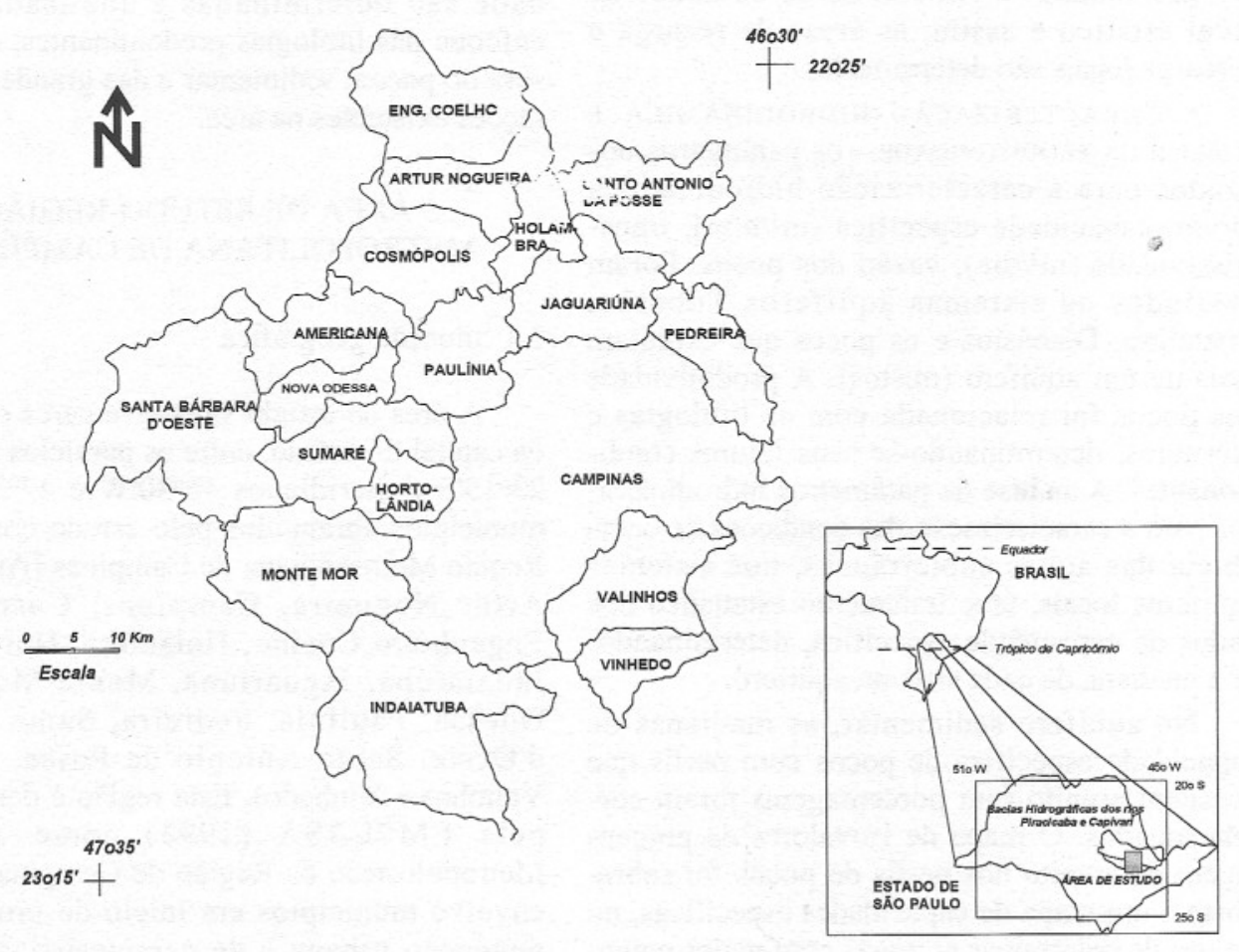

FIGURA 1 - Localização da área de estudo. 


\section{CONDIÇÕES DE OCORRÊNCIA DE ÁGUA SUBTERRÂNEA}

\subsection{Geometria dos sistemas aqüíferos}

Na Região Metropolitana de Campinas distinguem-se dois grandes sistemas aqüíferos regionais: o Sistema Aqüífero Tubarão, representado aqui pelos sedimentos permo-carbonífero do Subgrupo Itararé; o Sistema Aqüífero Cristalino, composto por rochas ígneas e metamórficas de natureza granítica e gnáissica do Complexo Itapira, Granitóide Jaguariúna e Granitos Morungaba e Itu, de idade precambriana e cambro-ordoviciana. Subordinadamente, as rochas de diabásio da Formação Serra Geral constituem-se em aqüíferos locais, limitantes quanto a sua extensão: são corpos pequenos distribuídos irregularmente por toda a área de estudo e às diversas profundidades. Os maiores corpos aflorantes encontram-se na parte central do município de Campinas e ao norte da área em Santo Antônio da Posse. A FIGURA 2 apresenta uma síntese da geologia da área de estu- do e a localização dos sistemas aqüíferos, baseados nos trabalhos do IG, 1993; IG, 1995; SOUZA FILHO, 1986; BASEI, CAMPOS NETO, BERGMAN \& FIGUEIREDO, 1986; VLACH, 1993; CPRM, 1974; DAEE/UNESP, 1982.

\subsubsection{Sistema Aqüífero Cristalino}

O Sistema Aqüífero Cristalino está aflorante na porção leste da Região Metropolitana de Campinas, ocupando uma área de $1117 \mathrm{~km}^{2}$, comportando os municípios de Vinhedo, Valinhos, Pedreira e Jaguariúna e partes de Campinas, Indaiatuba e Santo Antônio da Posse.

Em termos geomorfológicos, esse sistema situa-se no Planalto de Jundiaí (Planalto Atlântico), de relevo acidentado e possuidores das maiores altitudes e declividades da área de estudo.

As rochas componentes (gnaisses diversos e granitos intrusivos) apresentam diversos tipos de fraturamentos, que condicionam o armazenamento e transmissão da água subterrânea em terrenos cristalinos. As Zonas de Cisalhamento Campinas e Valinhos constituem-se das estru-

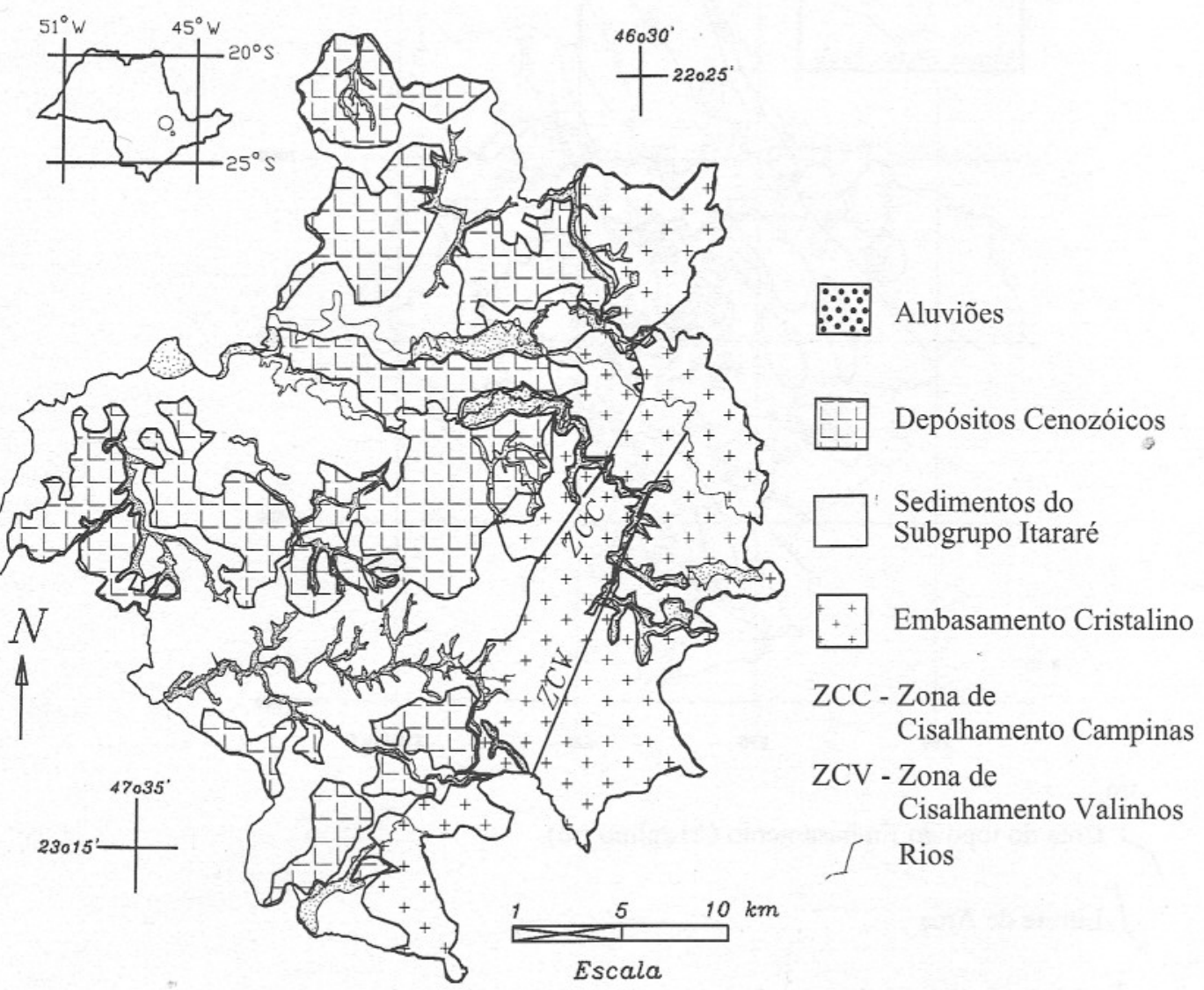

Fonte: IG (1993); IG (1995); SOUZA FILHO (1986); BASEI, CAMPOS NETO, BERGMAN \& FIGUEIREDO (1986); VLACH (1993); CPRM (1974); DAEE/UNESP (1982)

FIGURA 2 - Mapa geológico esquemático da área de estudo. 
turas mais notáveis da área: possuem direção $\mathrm{NE}$ e largas faixas de rochas milonitizadas. As mudanças abruptas das trajetórias dos rios Jaguari e Atibaia, praticamente, denunciam o fenômeno de movimentação dessas zonas.

Secundariamente, as falhas normais de direção NE e NS e as falhas transcorrentes e de cavalgamento, de sentido NW e EW são vistas na parte do extremo leste e norte da área. Em geral, o Sistema Aqüífero Cristalino apresenta-se bastante fraturado: praticamente todas as drenagens estão condicionadas às estruturas do terreno.

Nas áreas de ocorrência das zonas de cisalhamento e na área entre elas, a direção predominante N40E (aproximada) de fotolineamentos são concordantes a essas estruturas (IG, 1993).

$\mathrm{Na}$ parte central e à oeste, o Sistema Aqüífero Cristalino é encoberto pelos sedimentos do Subgrupo Itararé, onde se inicia a Bacia Sedimentar do Paraná na área de estudo. A
FIGURA 3 apresenta o possível contorno do embasamento cristalino na bacia.

Inicialmente, há um caimento gradacional logo após o contato com os sedimentos do Subgrupo Itararé, em toda a extensão da borda da bacia, seguindo, também, a direção desse contato (nordeste).

$\mathrm{Na}$ parte central e oeste da área, os desníveis topográficos do cristalino são notados, revelando uma superfície bastante acidentada. Existem altos estruturais (a mais alta chegando à cota topográfica de $600 \mathrm{~m}$ dentro do Subgrupo Itararé), dispostos em direção NE, indicando regiões mais elevadas e possíveis estruturas nessa direção. Na parte norte e principalmente à sudoeste da área de estudo, é nítida a presença de "baixos estruturais".

$\mathrm{Na}$ área da bacia hidrográfica de Capivari (município de Monte Mor), o baixo estrutural observado atinge profundidades consideráveis.
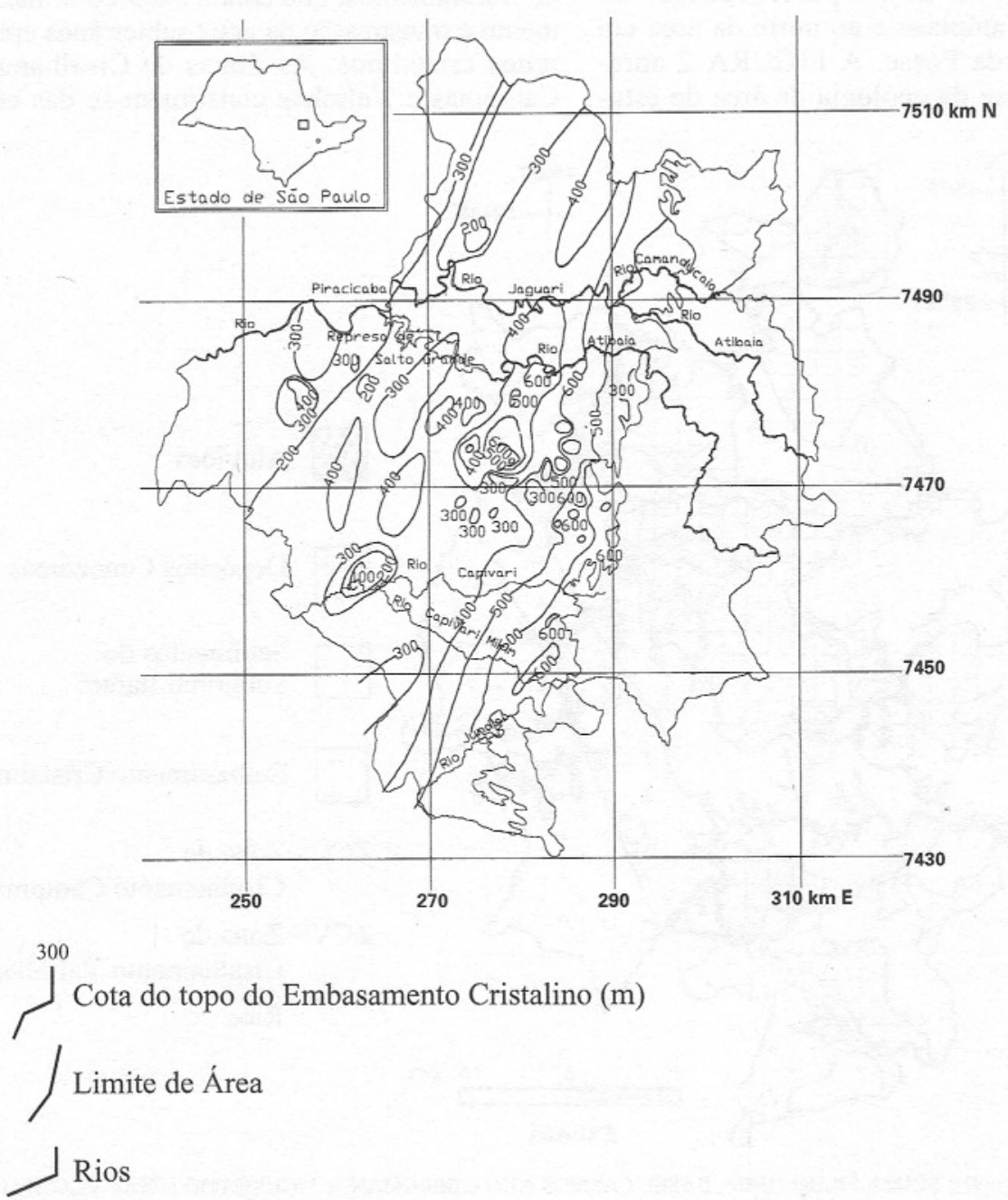

Fonte: modificado e adaptado de IG (1993) e IG (1995)

FIGURA 3 - Mapa de contorno estrutural do embasamento cristalino. 
A análise dos perfis de poços tubulares profundos indicam a existência de sedimentos abaixo da cota topográfica de $100 \mathrm{~m}$, ou espessuras do pacote sedimentar da ordem de 500 metros.

É interessante observar em superfície, a concordância do baixo estrutural, com a presença de sedimentos lamíticos do Subgrupo Itararé, onde há mudanças bruscas do tipo de relevo para colinas pequenas em direção EW.

$\mathrm{Na}$ parte norte, as evidências superficiais não são nítidas em uma primeira análise. As descontinuidades EW existentes na FIGURA 3 (mapa de contorno estrutural) delimitam os blocos estruturais de alta e baixas elevações.

Estas configurações do contorno do cristalino sotoposto ao Subgrupo Itararé, determinadas pela análise dos perfis geológicos dos poços tubulares profundos, são concordantes aos blo$\cos$ estruturais definidos por PIRES NETO (1996) e apresentados na FIGURA 4. Os baixos estruturais existentes na porção norte e sudoeste da área de estudo e o alto estrutural na parte central, seriam correspondentes à parte limítrofe sul do Bloco Pirapitingui, Bloco Mumbuca e ao Bloco Americana, respectivamente.

Na porção sul da área de estudo o lineamento Porto Feliz-Jacutinga delimita o Bloco Estrutural Capivari do Bloco Viracopos-Indaiatuba que, por sua vez, é limitado em sua parte norte pelo Bloco Americana e à leste pelo Bloco Mumbuca.

Na parte aflorante do cristalino, há a presença do Bloco Campinas, definido pelo lineamento - Araçoiaba-Jacutinga e Zona de Cisalhamento de Valinhos, do Bloco Jaguariúna no extremo nordeste; Bloco Jundiaí e Itu ao sul da área (PIRES NETO, 1996).

O manto de alteração nas rochas cristalinas apresenta-se nesse aqüífero com espessuras variando de 0 a $50 \mathrm{~m}$. Sua composição granulométrica varia de argilosa a arenosa, dependendo da

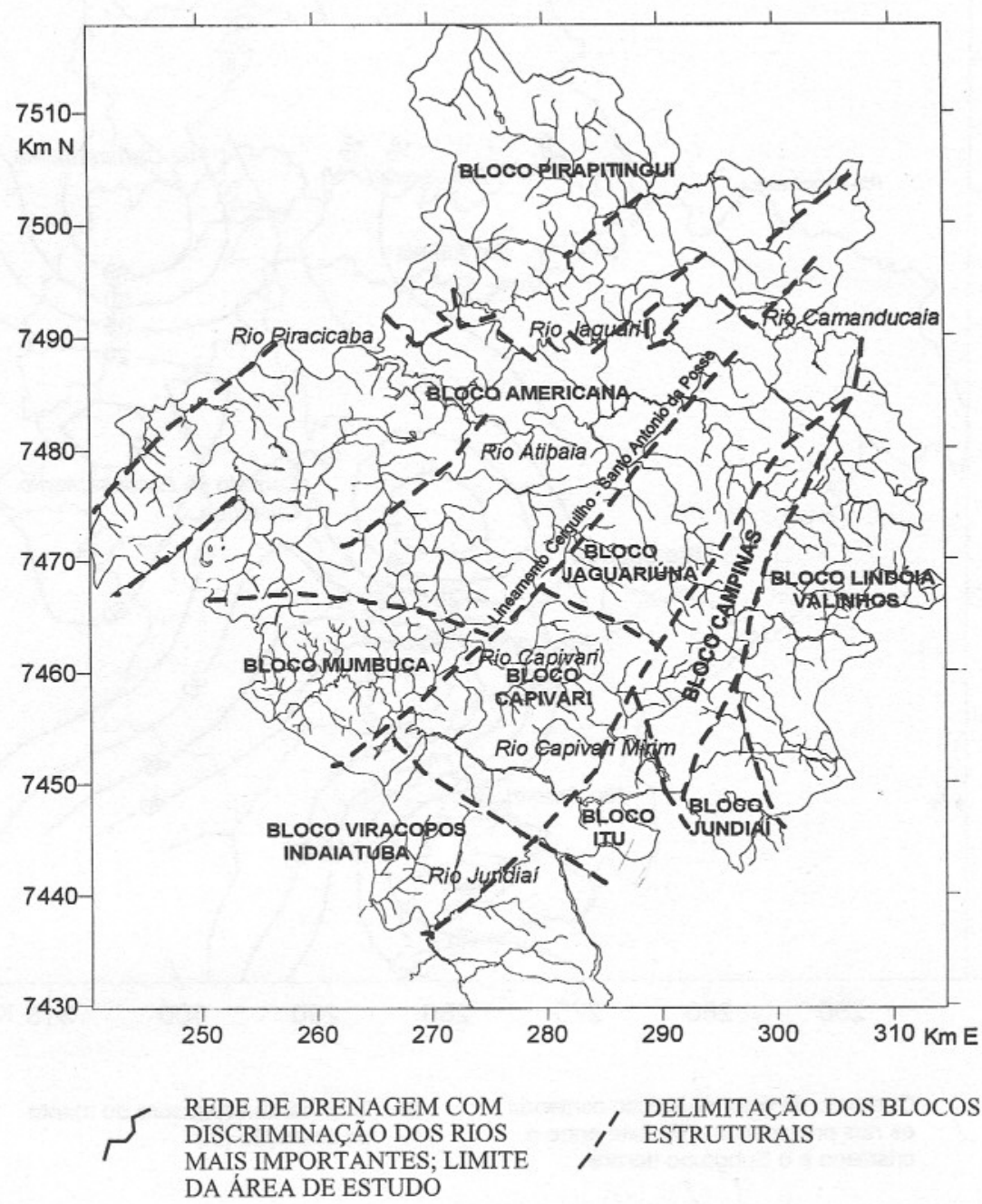

FIGURA 4 - A situação dos blocos estruturais na Região Metropolitana de Campinas (PIRES NETO, 1996). 
composição mineral e textural da rocha mãe e caracteriza-se como material friável, não consolidado.

Os maiores valores de espessura do manto de alteração ocorrem no contato entre o Embasamento Cristalino e a Bacia Sedimentar do Paraná e nas rochas gnáissicas do Complexo Itapira, principalmente na parte sudeste e centro-leste da área (FIGURA 5).

Essas ocorrências do manto de alteração são encontradas nas superfícies mais arrasadas do cristalino; os tipos de relevo predominantes são as colinas e morrotes, morros e morrotes. As rochas graníticas possuem a maior resistência ao intemperismo físico e químico em detrimento dos gnaisses; conseqüentemente apresentam os terrenos de maiores elevações topográficas e os relevos mais acidentados (escarpas), como também os mais baixos valores de espessura de manto de alteração.

As rochas do Complexo Itapira apresentam maiores números de espessura do manto, cuja distribuição espacial segue a disposição dessas litologias na área: uma faixa alongada de direção nordeste, justamente entre as Zonas de Cisalhamento Campinas e Valinhos.

Ao sul do embasamento cristalino, as maiores espessuras do manto se estende para sudeste, abrangendo os municípios de Valinhos e Vinhedo,

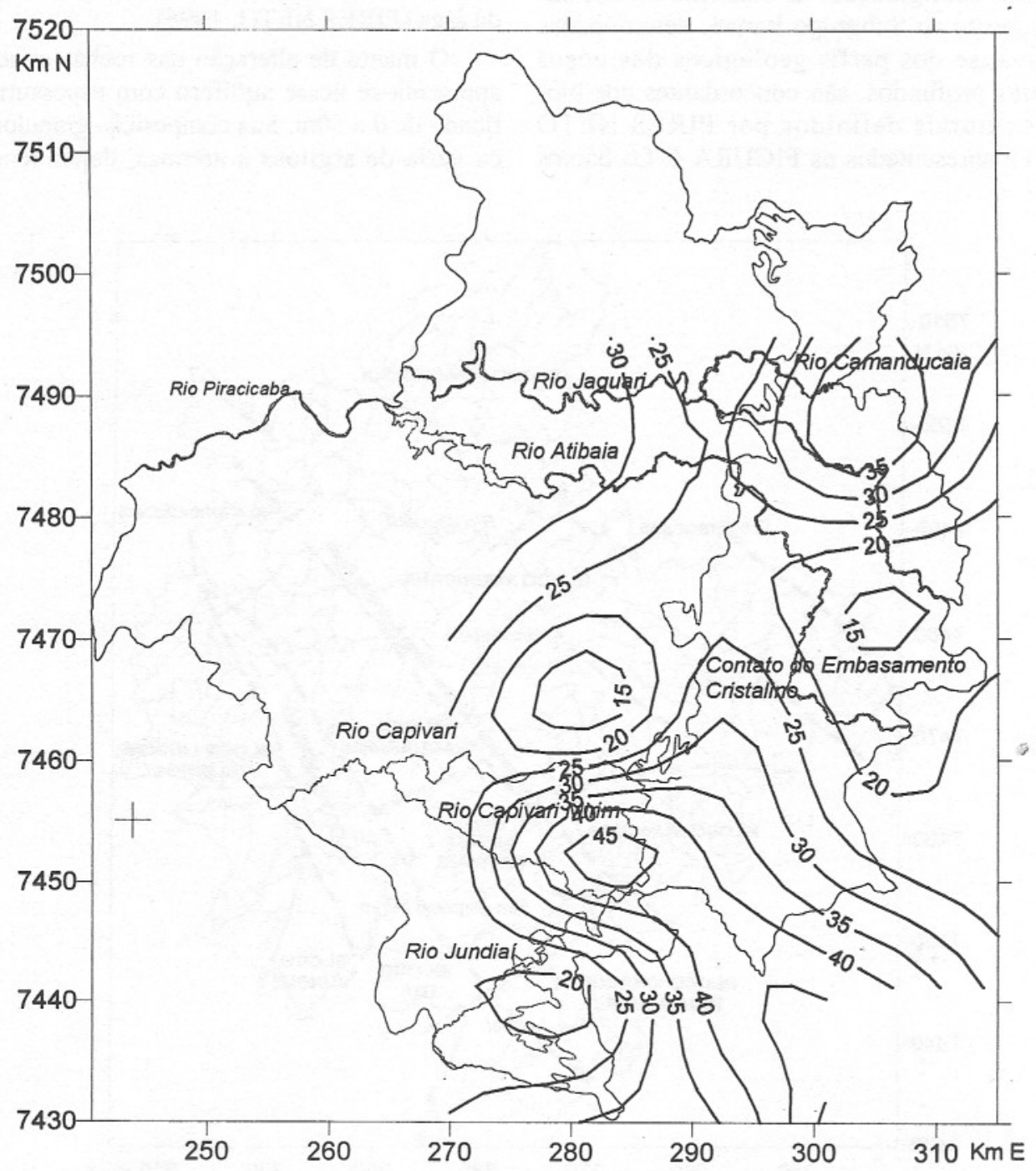

\footnotetext{
C Contorno da área de estudo contendo os rios principais e o contato entre 0 cristalino e o Subgrupo Itararé
}

90 Isolinha da espessura do manto de alteração $(\mathrm{m})$

FIGURA 5 - Distribuição espacial do manto de alteração no embasamento cristalino na Região Metropolitana de Campinas. 
formando uma outra faixa, de direção noroeste. Essa tendência direcional das espessuras consideráveis do manto aparece, também, na porção central e no extremo norte da área e, provavelmente pode estar relacionada às grandes estruturas de direção noroeste existentes na região.

\subsubsection{Sistema Aqüífero Tubarão: o Aqüífero Itararé}

O Aqüífero Itararé é ocorrente na porção centro-oeste e à oeste da Região Metropolitana de Campinas, em contato discordante e erosivo com o embasameto cristalino.

Os sedimentos de Subgrupo Itararé na região representariam ambientes deposicionais distintos: as associações faciológicas de sedimentos pelíticos (ritmitos e diamictitos, lamitos com seixos) seriam depositados em ambiente de plataforma, como correntes de turbidez e produtos de retrabalhamento de depósitos glaciais em ambiente marinho; as associações de arenitos são resultantes da deposição de sedimentos em sistemas deltáicos. Essas litologias apresentam-se muito litificadas e algumas vezes com estruturas rúpteis (IG, 1995).

Os sedimentos lamíticos possuem maior área aflorante na região, geralmente formados por relevos originários de processos de dissecação (colinas pequenas). Em geral, os arenitos afloram nos topos, na parte superior das vertentes ou em relevos de formas mais suaves (as colinas).

A espessura dos sedimentos aumenta para oeste, em direção ao centro da Bacia Sedimentar do Paraná. No entanto, as variações de espessura dos sedimentos são concordantes com a morfologia do embasamento cristalino: assim, as maiores espessuras de sedimentos encontram-se na bacia hidrográfica do rio Capivari, nos municípios de Monte Mor, Hortolândia e Americana, onde são observadas espessuras da ordem de 300 a $400 \mathrm{~m}$ em poços tubulares profundos. Ao norte da área (próximo ao município de Engenheiro Coelho), espessuras consideráveis, da ordem de $300 \mathrm{~m}$, também são encontradas.

Os corpos intrusivos de diabásios estão distribuídos em diversos tamanhos e às diversas profundidades. As duas maiores extensões de corpos de diabásio situam-se na parte central (Campinas) e ao norte da área (Santo Antônio da Posse).

A análise da porcentagem e da espessura de arenitos em perfis geológicos de poços tubulares profundos indicam maior concentração dessa litologia em subsuperfície dispostas em uma larga faixa, que se inicia na porção oeste da área (Santa Bárbara d'Oeste, Americana e Nova Odessa) e finaliza nas cabeceiras da Bacia do Rio Capivari (chegando a $85 \%$ ). Secundariamente, na porção centro-norte (arredores do Rio Jaguari, nos municípios de Holambra e de Cosmópolis), também há ocorrências de valores significativos da espessura e porcentagem da espessura de arenito (FIGURA 6).

\subsubsection{Diabásios}

Os corpos de diabásios, intrusivos na porção sedimentar da área de estudo e em alguns pontos no embasamento cristalino, apresentam-se em forma de diques, sills, lacólitos ou corpos irregulares de diversos tamanhos e a várias profundidades. IG (1995) determina que em subsuperfície, os diabásios são encontrados como corpos irregulares alojados, preferencialmente, na interface entre o embasamento cristalino e a base dos sedimentos do Subgrupo Itararé, atingindo espessuras que podem superar $300 \mathrm{~m}$. O contato dessas rochas com as encaixantes é abrupto, muitas vezes subvertical.

Os maiores corpos aflorantes situam-se em Campinas (porção central) comportando uma área de cerca de $150 \mathrm{~km}^{2}$ e em Santo Antônio da Posse (nordeste da área), com $300 \mathrm{~km}^{2}$ de extensão.

A FIGURA 7 demonstra a distribuição dos corpos de diabásio em subsuperfície, concentrando-se em uma área que se estende da porção central a noroeste da área (de Campinas à Americana e proximidades). Os corpos de diabásio, de extensão limitada, estão distribuídos em direção preferencial NW e NE, concordantes com as principais direções estruturais da região, como também com a direção dos corpos de diabásio por todo o Estado de São Paulo.

\subsubsection{Cenozóico}

Os depósitos cenozóicos apresentam-se em grandes extensões, principalmente na porção leste e norte da região metropolitana e ao sul, em corpos menores. Esses sedimentos foram subdivididos em unidades litológicas como: coberturas arenosas, lamitos e arenitos pelíticos, siltitos/arenitos e areias com matriz argilosa são correspondentes à Formação Rio Claro, de idade Terciária (IG, 1995).

Esses sedimentos são pouco litificados e apresentam espessuras que podem atingir de 35 a $40 \mathrm{~m}$; ocorrem em topos de relevos suaves (colinas amplas e colinas amplas de topos subhorizontalizados), capeando sedimentos do Subgrupo Itararé e, subordinadamente diabásios e rochas do embasamento cristalino (IG, 1995).

Os depósitos cenozóicos comportam aqüíferos freáticos, dada sua posição estratigráfica (em áreas elevadas, correspondendo às áreas de recargas locais) e espessuras pouco expressivas, são considerados fontes de recarga dos aqüíferos mais 
importantes como também aqüíferos para captações de menor porte, como as cacimbas e as fontes.

\subsubsection{Aluviões}

Os aluviões correspondem aos sedimentos das planícies de inundação e terraços dos rios, constituídos de areias finas até grossas, sedimentos silto-argilosas com lentes de areia micácea fina a muito fina, argilas e siltes.

As maiores ocorrências desses sedimentos são encontradas nos rios Jaguari, Atibaia, Capivari e Jundiaí; apresentam-se com pouca espessura e um nível de água subaflorante a aflorante: trata-se de zonas locais de descargas de águas subterrâneas.
4.2 Circulação de Águas Subterrâneas -

condições de recargas e descargas locais

As águas subterrâneas exploradas pelos poços tubulares profundos na Região Metropolitana pertencem a um sistema de fluxo de caráter local, com forte influência das variações da topografia dos terrenos.

$\mathrm{O}$ embasamento cristalino, situado à leste da área, apresenta terrenos de cotas topográficas mais elevadas e, conseqüentemente, os maiores gradientes hidráulicos da área. Os sentidos divergentes de fluxo para as cotas mais baixas e a disposição menos espaçadas das linhas eqüipotenciais, observadas principalmente na porção sul da área, indicam a presença do divisor das águas subterrâneas e a área de recarga da região.

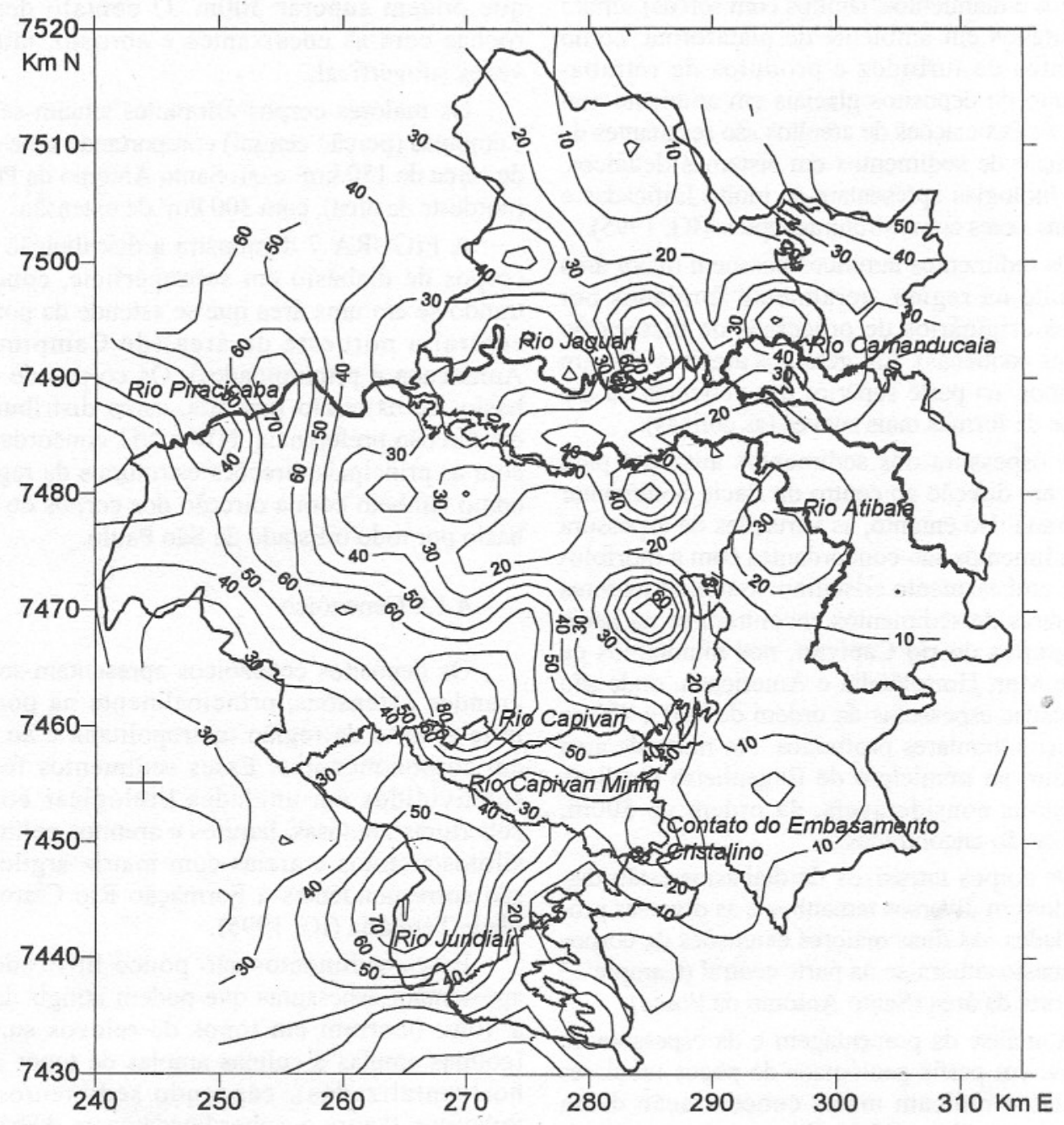
cristalino e o Subgrupo Itararé espessura de arenito $(\% \mathrm{~m})$

FIGURA 6 - Área de ocorrência de arenitos (em porcentagem de espessura) em subsuperfície na Região Metropolitana de Campinas. 
$\mathrm{Na}$ parte central e ao norte, algumas áreas de recargas locais podem ser visualizadas por meio da existência de divisores situados entre os rios Capivari e Atibaia e em terrenos situados na margem direita do rio Jaguari.

As áreas de descargas situam-se na porção centro-oeste e sudoeste, nos rios de maior porte como o Atibaia e o Jaguari (Represa de Salto Grande e arredores), o Capivari, o ribeirão Quilombo (afluente da margem esquerda do rio Piracicaba) e o rio Jundiaí.

\subsection{Caracterização Hidrodinâmica}

$\mathrm{Na}$ caracterização hidrodinâmica, são analisados, individualmente, os sistemas aqüíferos Tubarão, Cristalino e o aqüífero
Diabásio, como também áreas onde existem poços que explotam mais de um aqüífero. Os corpos de diabásio são considerados aqüíferos locais, devido a sua ocorrência em corpos de diversas dimensões e em profundidades variadas; sua produtividade está associada aos fraturamentos da rocha. Os sedimentos dos depósitos cenozóicos, ocorrentes em topos de relevos colinosos de grande amplitude, não são explotados pelos poços tubulares profundos da região, portanto não são avaliados nesse item.

O Sistema AqứfFero CRISTALINo apresenta-se na literatura como um aqüífero de extensão regional, de porosidade secundária (a circulação das águas ocorre nas fraturas das rochas), anisotrópico e heterogêneo, de comportámento semiconfinado a livre e descontínuo.

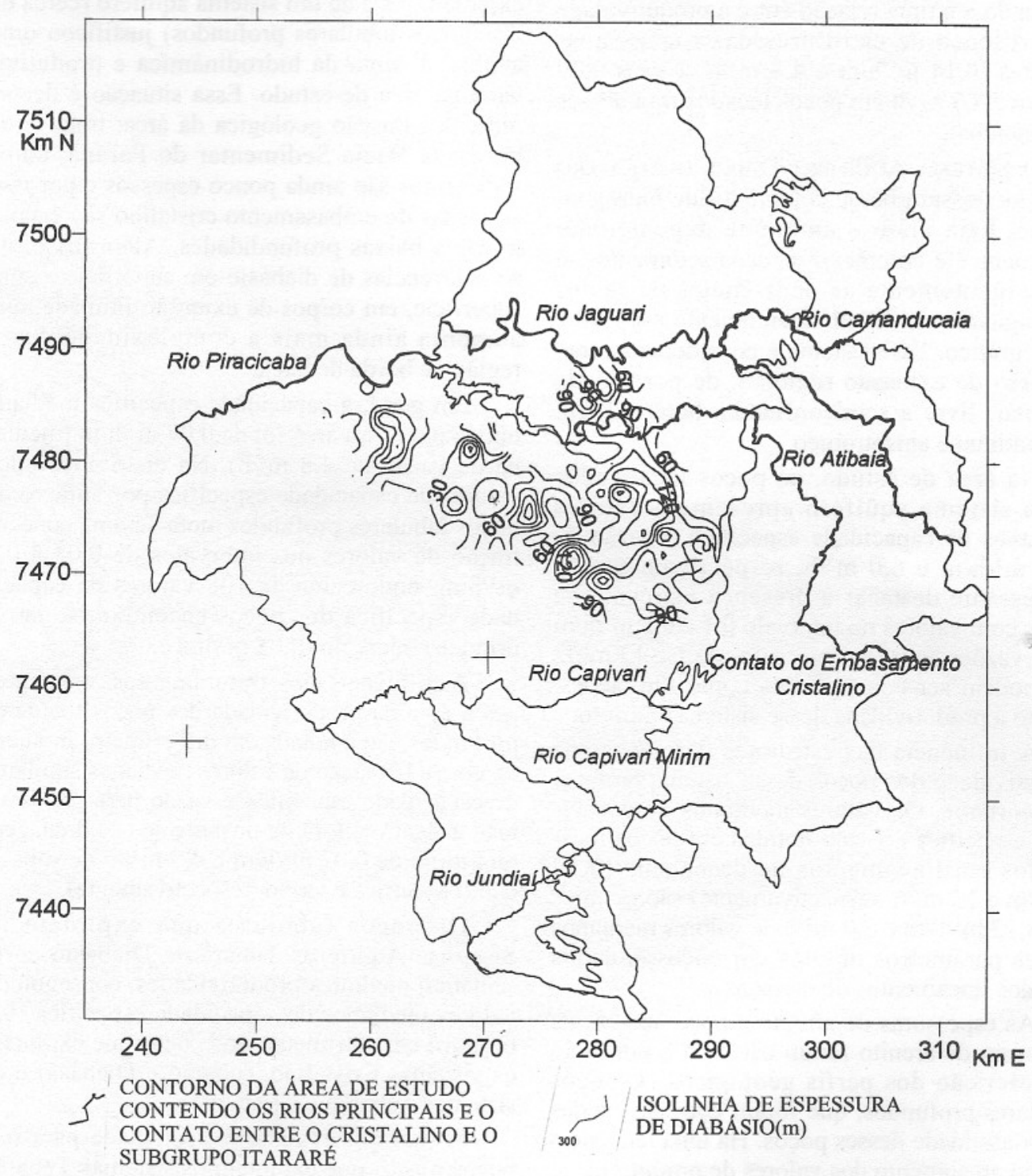

FIGURA 7 - Área de ocorrência de diabásios em superfície e em subsuperficie na Região Metropolitana de Campinas. 
$\mathrm{Na}$ caracterização hidrodinâmica dos 312 poços que explotam somente esse aqüífero, determinou-se uma capacidade específica mediana de $0,1 \mathrm{~m}^{3} / \mathrm{h}$ por metro de rebaixamento (média de $0,28 \mathrm{~m}^{3} / \mathrm{h} / \mathrm{m}$ ) e vazão mediana de 5,2 $\mathrm{m}^{3} / \mathrm{h}$ (média de $7,3 \mathrm{~m}^{3} / \mathrm{h}$ ).

A distribuição da capacidade específica e da vazão, onde os valores se concentram nos intervalos de 0,05 a $0,5 \mathrm{~m}^{3} / \mathrm{h} / \mathrm{m}$ (principalmente no intervalo 0,05 a 0,2$)$ e 1 a $10 \mathrm{~m}^{3} / \mathrm{h}$ (relevantemente no intervalo entre 1 a $6 \mathrm{~m}^{3} / \mathrm{h}$.

Os valores de transmissividade calculados para seis poços são: 0,$32 ; 0,13 ; 0,14 ; 0,18 ; 6,85$; 0,29 e $1,18 \mathrm{~m}^{2} /$ dia.

Os maiores valores medianos da capacidade específica dos poços e as vazões localizam-se dentro de lineamentos de drenagem, indicando a íntima relação entre a produtividade e a presença de estruturas das rochas hospedeiras $\left(0,14 \mathrm{~m}^{3} / \mathrm{h} / \mathrm{m}\right.$ e $4,8 \mathrm{~m}^{3} / \mathrm{h}$ versus 0,09 $\mathrm{m}^{3} / \mathrm{h} / \mathrm{m}$ e $4,7 \mathrm{~m}^{3} / \mathrm{h}$ em poços locados fora desses lineamentos).

O Sistema Aqứfero Tubarão-Aqüifero ITARARÉ possui grande complexidade hidrogeológica, haja visto o ambiente deposicional extremamente complexo de seus sedimentos, e conseqüentemente as ocorrências de fácies interdigitadas de difícil entendimento espacial e estratigráfico. Esse sistema é considerado como aqüífero de extensão regional, de porosidade granular, livre a semiconfinado, heterogêneo, descontínuo e anisotrópico.

$\mathrm{Na}$ área de estudo, os poços localizados nesse sistema aqüífero apresentam valores medianos de capacidade específica e vazão de $0,11 \mathrm{~m}^{3} / \mathrm{h} / \mathrm{m}$ e $6,0 \mathrm{~m}^{3} / \mathrm{h}$, respectivamente. É interessante destacar a presença marcante de poços com valores no intervalo 0,1 e $0,2 \mathrm{~m}^{3} / \mathrm{h} / \mathrm{m}$ e das vazões, entre os intervalos de 1 a $12 \mathrm{~m}^{3} / \mathrm{h}$, que podem ser considerados como limitações, quanto à produtividade desse sistema aqüífero.

A influência das estruturas das rochas na produtividade dos poços desse sistema também é importante. Os valores medianos de capacidade específica e vazão obtidos em poços localizados em lineamentos de drenagens $(0,14$ $\mathrm{m}^{3} / \mathrm{h} / \mathrm{m}$ e $12 \mathrm{~m}^{3} / \mathrm{h}$, respectivamente) são maiores que $0,12 \mathrm{~m}^{3} / \mathrm{h} / \mathrm{m}$ e $7,0 \mathrm{~m}^{3} / \mathrm{h}$ de valores medianos desses parâmetros obtidos em poços situados fora dos lineamentos de drenagem.

As espessuras de arenito e porcentagem da espessura de arenito foram calculadas por meio da descrição dos perfis geológicos de poços tubulares profundos, que foram correlacionadas à produtividade desses poços. Há uma tendência quanto ao aumento dos valores de produtividade em função da presença de arenito em maiores porcentagens.
O AQỨífERo DiABÁsio apresenta os mais baixos valores medianos de capacidade específica e vazão $\left(0,06 \mathrm{~m}^{3} / \mathrm{h} / \mathrm{m}\right.$ e $\left.4,5 \mathrm{~m}^{3} / \mathrm{h}\right)$ encontrados na região metropolitana. A distribuição dos valores de capacidade específica e vazão indicam maiores concentrações nos intervalos mais baixos $\left(0\right.$ a $0,01 \mathrm{~m}^{3} / \mathrm{h} / \mathrm{m}$ e entre 0 a $1 \mathrm{~m}^{3} / \mathrm{h}$, respectivamente).

A produtividade desse aqüífero está condicionada aos fraturamentos existentes na rocha, corroborada com a determinação de uma capacidade específica mediana de $0,12 \mathrm{~m}^{3} / \mathrm{h} / \mathrm{m}$ em poços locados dentro de lineamentos de drenagens, em detrimento do valor conseguido de $0,05 \mathrm{~m}^{3} / \mathrm{h} / \mathrm{m}$, mediana dos valores determinados em poços situados fora dos lineamentos.desses.

A grande quantidade de poços que explotam mais de um sistema aqüífero (cerca de 271 poços tubulares profundos) justificou uma análise distinta da hidrodinâmica e produtividade na área de estudo. Essa situação é decorrente da situação geológica da área: trata-se da borda da Bacia Sedimentar do Paraná, cujos sedimentos são ainda pouco espessos e por isso as rochas do embasamento cristalino são encontradas a baixas profundidades. Além disso, há as ocorrências de diabásio em superfície e subsuperfície, em corpos de extensão limitada, que aumenta ainda mais a complexidade dessa região de borda de bacia.

Em geral, a capacidade específica mediana obtida para essa área foi de $0,07 \mathrm{~m} / \mathrm{h} / \mathrm{m}$ (mediana de vazão de $4,8 \mathrm{~m}^{3} / \mathrm{h}$ ). Na distribuição dos valores de capacidade específica por número de poços tubulares profundos, nota-se uma concentração de valores nos intervalos de 0,05 a 0,3 $\mathrm{m}^{3} / \mathrm{h} / \mathrm{m}$, onde cerca de 108 valores de capacidade específica dos poços encontram-se nesse primeiro intervalo $\left(0,05 \mathrm{~m}^{3} / \mathrm{h} / \mathrm{m}\right)$.

A influência dos fraturamentos, existentes nessa área na produtividade dos poços tubulares profundos não é notada em um primeiro momento, com a obtenção de valores medianos similares de capacidade específica e vazão para poços situados dentro e fora de lineamentos de drenagem (em torno de $0,07 \mathrm{~m}^{3} / \mathrm{h} / \mathrm{m} \mathrm{e} 4,5 \mathrm{~m}^{3} / \mathrm{h}$ de capacidade específica e vazão, respectivamente).

Os poços tubulares que explotam os Sistemas Aqüíferos Tubarão e Diabásio apresentaram melhores produtividades, conseguindo valores medianos de capacidade específica $(0,1$ $\mathrm{m}^{3} / \mathrm{h} / \mathrm{m}$ ) em detrimento dos poços que explotam os sistemas Cristalino Tubarão e Diabásio e os sistemas Tubarão e Cristalino.

A transmissividade foi calculada para três poços mistos que explotam os sistemas Tubarão e Cristalino, obtendo-se valores de 0,$113 ; 2,77$ e $0,71 \mathrm{~m}^{2} / \mathrm{dia}$. 
4.4 Análise da Produtividade dos poços tubulares profundos

A distribuição espacial dos valores de capacidade específica revelou tendências de comportamento bem distintas na área de estudo.

No Sistema Aqüífero Cristalino, a produtividade dos poços tubulares profundos está relacionada aos diversos tipos de estruturas existentes nesses terrenos, definidos pelos grandes lineamentos de drenagens de direção NE e EW, como também pelo mapa geológico.

A análise dos valores de capacidade específica foi executada por meio de compartimentações baseados nas grandes estruturações existentes e pelos modelos de blocos estruturais propostos por PIRES NETO (1996).

A FIGURA 8 apresenta as compartimentações definidas pelas produtividades similares e estruturas.

O Bloco Lindóia-Valinhos (na parte leste de Campinas e Pedreira) não foi considerado para análise, pela inexistência de informações. Os terrenos são topograficamente elevados e acidentados e de baixa ocupação humana.

$\mathrm{Na}$ área de ocorrência das rochas do Complexo Itapira de composição granítica, observa-se boas produtividades nos poucos poços existentes (de intervalo de 0,35 a 8,5 $\mathrm{m}^{3} / \mathrm{h} / \mathrm{m}$ ). A região localizada entre os rios Atibaia e Jaguari apresenta-se bastante fratura$\mathrm{da}$, haja visto a ocorrência de fortes estruturações de direções NW e NNE, visualizada pela alta densidade de drenagem local. As rochas aflorantes nesse local pertencem ao Granito Morungaba, de caráter homogêneo, e as rochas granitóides do Complexo Itapira.

Essas características estruturais e litológicas sugerem um bom potencial de produtividade de poços, pois indicam grande número de juntas e fraturas por onde a água circula.

Ao sul da área, no Bloco Jundiaí, as rochas gnáissicas do Complexo Itapira são predominantes; há ocorrências no canto leste do Granito Morungaba, caracterizadas por relevos de topografia elevada e escarpadas.

Já as rochas gnássicas comportam relevos menos acidentados, como os morros e morrotes e colinas e morrotes, e uma menor densidade de drenagem. As estruturações observadas possuem direção NW e algumas com forte inflexão para NE, seguindo a Zona de Cisalhamento Valinhos.

No cômputo geral, o potencial produtivo é considerado mediano, onde a produtividade dos poços está relacionada com os lineamentos de padrões NW e NNW. A primeira direção seria condicionante das drenagens principais e a segunda direção, resultante das movimentações de deslocamento (os falhamentos normais).

A exceção é feita nas proximidades do lineamento que separa o Bloco Lindóia-Valinhos do Jundiaí, que mais ao leste vem a constituir no Lineamento do Interflúvio Jundiaí-Atibaia (PIRES NETO, 1996).

Os poços localizados nessa área possuem bons valores de capacidade específica (situados nos intervalos entre 0,13 a 0,35 e 0,35 e 8 $\left.\mathrm{m}^{3} / \mathrm{h} / \mathrm{m}\right)$.

No Bloco Campinas, apesar do pequeno número de poços tubulares com valores de capacidade específica, verifica-se três tendências de produtividade: os altos valores, situados ao longo da Zona de Cisalhamento de Valinhos e na porção sul; os valores intermediários e os valores baixos, situados entre a Zona de Cisalhamento Campinas e a região de altos valores.

No Bloco Itu, ao sul do Bloco Campinas, os poços tubulares apresentam bom potencial produtivo, com tendência a um decréscimo desse potencial na porção limítrofe à Zona de Cisalhamento Valinhos. As principais estruturas possuem direção EW e NE; a tendência de melhor produtividade parece situar-se ao longo dos fraturamentos de direção EW.

O Bloco Jaguariúna situa-se entre a Zona de Cisalhamento Campinas e o Lineamento Porto Feliz-Jacutinga, no contato do embasamento cristalino e em parte da bacia sedimentar. Ao longo da zona de cisalhamento são observados poços com boa produtividade. Nas áreas restantes, essa produção está relacionada com fortes estruturações de direção $\mathrm{EW}$, condicionantes dos rios de maior porte na região, como os rios Jaguari, Atibaia e o Camanducaia.

Nos terrenos próximos ao limite desse bloco estrutural com o Bloco Capivari, e nessa própria compartimentação, visualizam-se baixos valores de produtividade. Na área entre os rios Capivari e Capivari-Mirim, são encontrados altos valores de capacidade específica.

De um modo geral, as melhores produtividades do Sistema Aqüífero Cristalino encontram-se ao longo do contato do embasamento cristalino com a bacia sedimentar, bem como a existência de tendências de bons potenciais de produção em lineamentos de drenagem de direção EW e NE.

A produtividade dos poços parece acompanhar, também, o caimento ocasionado pela movimentação dos blocos estruturais. Desse modo, no Bloco Jaguariúna uma tendência de boa produtividade aparece a noroeste do bloco, que possui um caimento suave na mesma direção. 
No Bloco Itu, as maiores produtividades se encontram na porção noroeste, concordantes com a direção do caimento desse bloco estrutural; o mesmo é ocorrente no Bloco Jundiaí, com adernamento recente para noroeste.

O Aqüífero Itararé apresenta uma distribuição mais caótica dos valores de capacidade específica, coerente com a complexidade faciológica de sedimentos de ambiente de plataforma e avanços e recuos de geleiras. No entanto, existem tendências de distribuição dos valores desse parâmetro.
As áreas com menores produtividades situam-se ao longo do contato do aqǘf́rero sedimentar com o cristalino, parte de Campinas e Indaiatuba, e na porção central da região metropolitana, abrangendo os municípios de Paulínia, Sumaré, Nova Odessa, Artur Nogueira e Jaguariúna (FIGURA 9).

Os valores intermediários são encontrados na parte norte da área, envolvendo os municípios de Holambra e Santo Antônio da Posse.

As regiões com alta potencialidade produtiva são encontradas na porção sudoeste (princi-

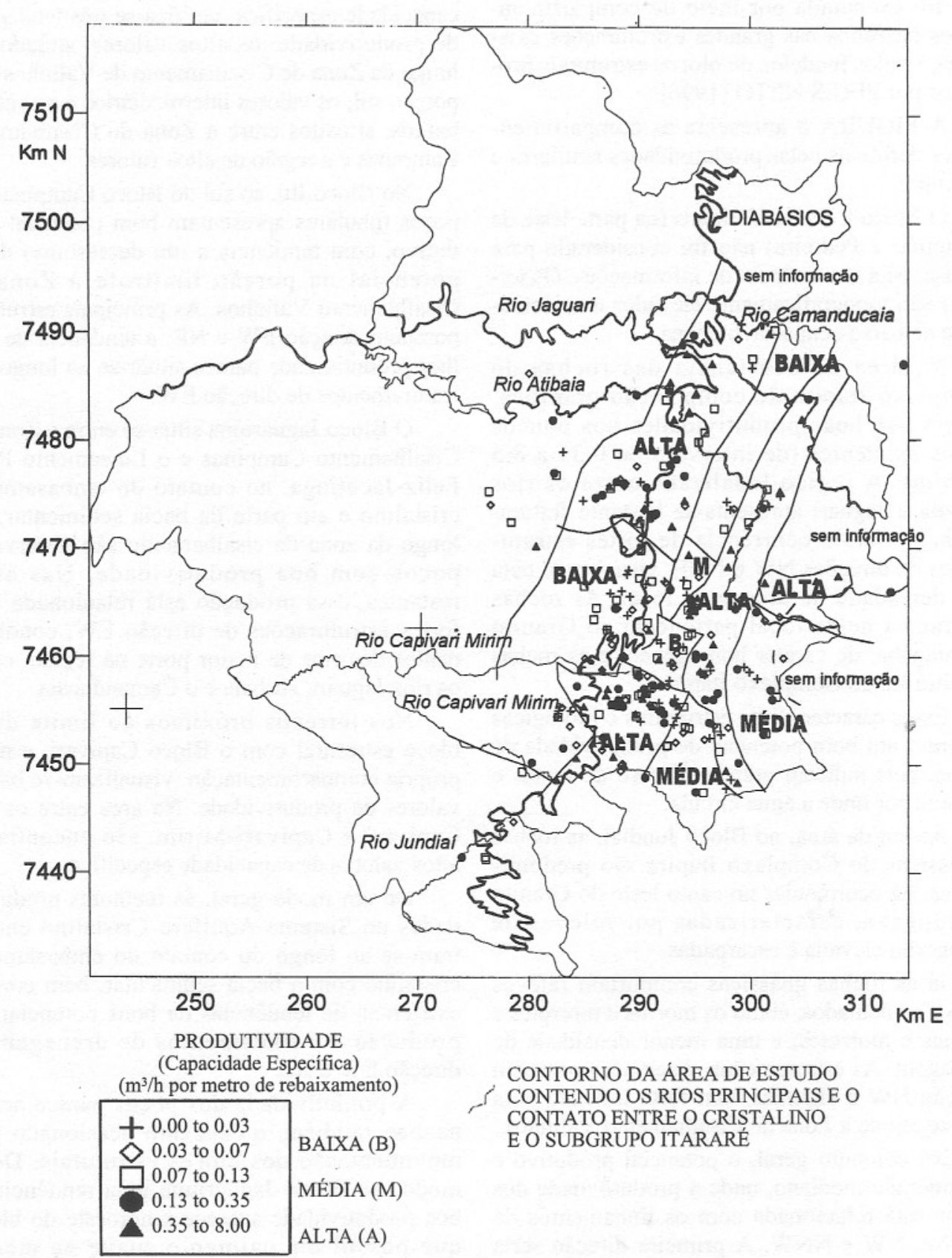

FIGURA 8 - Distribuição espacial da produtividade no Sistema Aqüífero Cristalino. 
palmente Santa Bárbara d'Oeste e Monte Mor), à noroeste (nas proximidades da Represa de Salto Grande, estendendo em faixa para nordeste, englobando a parte oeste de Artur Nogueira e Engenheiro Coelho) e na parte central da área de estudo (oeste de Campinas, Hortolândia e Paulínia).

Esses terrenos altamente produtivos do Aqüífero Itararé podem estar relacionados com a disposição de sedimentos mais arenosos de subsuperfície. Em termos de compartimentação estrutural, as maiores produtividades situam-se no Bloco Mumbuca e porção sudoeste-oeste do Bloco Americana, que comportam as maiores espessuras de sedimentos da região. Na porção noroeste do Bloco Americana, oeste do Bloco Pirapitingui e na parte norte do Bloco Capivari, os altos valores de produção dos poços tubulares são encontrados.

Nos poços locados em diabásios, a espacialização das produtividades também apresentou tendências. Os valores baixos encontram-se no corpo aflorante em Campinas. Ao longo da faixa de ocorrência de corpos de diabásios na área de

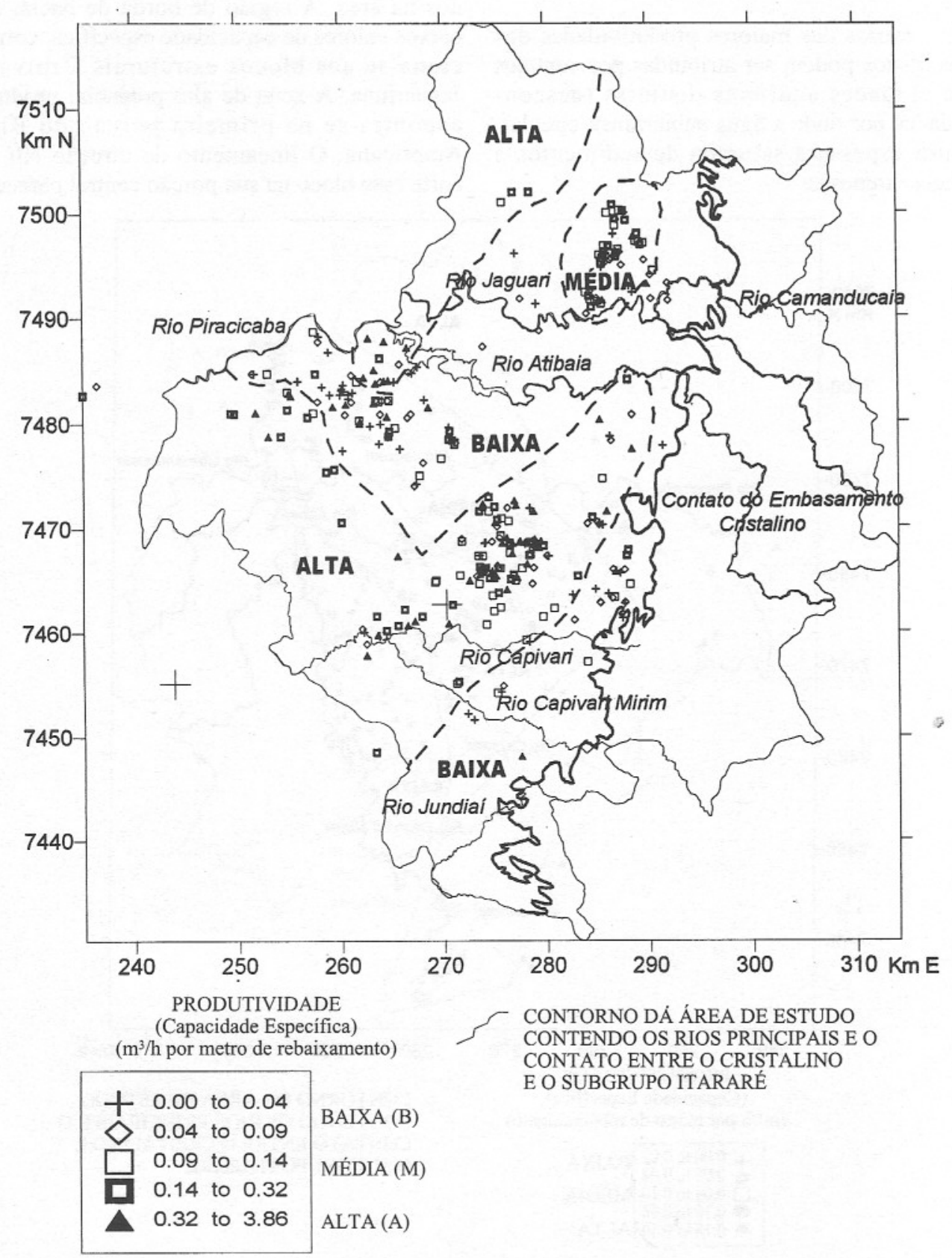

FIGURA 9 - Distribuição espacial da produtividade no Sistema Aqüífero Tubarão - Aqüífero Itararé. 
estudo, verifica-se uma alternância de zonas de altas e baixas produtividades, apesar da existência de pouca informação disponível.

Os poços mistos, que explotam mais de um sistema aqüífero, apresentam zonas bem distintas de produtividade. A região de menor potencial situa-se ao longo do contato de embasamento cristalino, seguida de uma área de alta produtividade e de uma de valores intermediários. Na região que engloba principalmente Engenheiro Coelho, Artur Nogueira e Santa Bárbara d'Oeste, a alta produtividade dos poços novamente se faz presente (FIGURA $10)$.

As causas das maiores produtividades dos poços mistos podem ser atribuídas por contatos entre unidades aqüíferas distintas (descontinuidades por onde a água subterrânea circula), a maior espessura saturada de sedimentos e litologias arenosas.
Nas porções de borda de bacia, onde ocorrem os menores valores de capacidade específi$\mathrm{ca}$, os sedimentos são poucos espessos e freqüentemente nos contatos entre as unidades aqüíferas, são colocados os revestimentos dos poços.

À medida que se penetra na bacia sedimentar, a espessura (saturada) aumenta e a produção de água subterrânea das descontinuidades são então computadas, juntamente com a produção da maior espessura saturada.

As zonas de produtividade podem ser correlacionadas com os blocos estruturais encontrados na área. A região de borda de bacia, com baixos valores de capacidade específica, correlaciona-se aos blocos estruturais Capivari e Jaguariúna. A zona de alto potencial produtivo encontra-se na primeira porção do Bloco Americana. O lineamento de direção NE que corta esse bloco na sua porção central parece ser

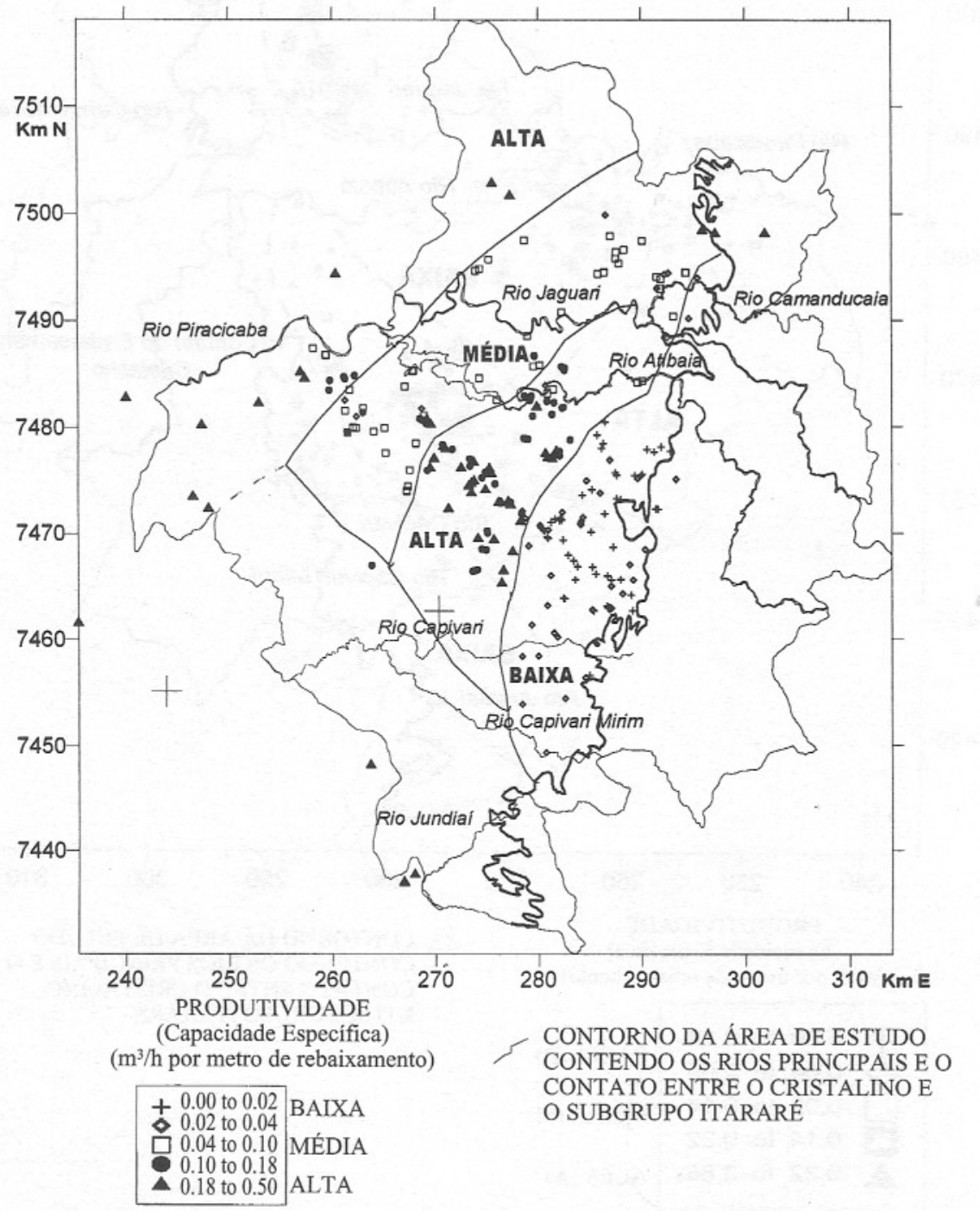

FIGURA 10 - Distribuição espacial da produtividade dos poços que explotam mais de um aqǘfero (poços mistos). 
o limite de compartimentação do alto potencial produtivo para outro de valores intermediários atingindo, também, o Bloco Pirapitingui. Por fim, um segundo lineamento observado mais a oeste do Bloco Americana e que se estende ao Bloco Pirapitingui delimita a área de alto potencial produtivo.

O sentido de movimentação de alguns blocos estruturais é também concordante com as áreas de maior produtividade. No Bloco Mumbuca, há um soerguimento com adernamento para sul em direção aos rios Capivari e Tietê, que parece estar concordante com os altos valores de capacidade específica encontradas nos poços ali situados.

\section{CONCLUSÕES}

A caracterização hidrogeológica dos sistemas aqüíferos regionais, Tubarão (no caso o Aqüífero Itararé) e Cristalino, as ocorrências de diabásios e os depósitos cenozóicos determinaram a influência dos condicionantes estruturais na delimitação da geometria dos aqüíferos e na produtividade das águas subterrâneas.

As estruturas de grande porte e os blocos estruturais compartimentam o Sistema Aqüífero Cristalino e são responsáveis pela circulação de água subterrânea em fraturas, como também pela maior ou menor produtividade dos poços, juntamente com as fraturas e falhas normais existentes. A presença de manto de alteração com espessuras significativas em parte da área, caracteriza um outro modo de ocorrência das águas subterrâneas, por porosidade primária na parte superior desse sistema aqüífero.

O Sistema Aqüífero Tubarão, representado na região metropolitana pelo Aqüífero Itararé, está aflorante na sua porção central e oeste. O pacote sedimentar aumenta sua espessura para oeste da área, porém há a existência de "altos" e "baixos" estruturais de direção NE sotoposto a esse pacote.
Em subsuperfície, há a ocorrência de sedimentos arenosos em uma faixa de grande extensão, cortando em sentido NW-SE, situada no quadrante sudoeste da área de estudo.

A produtividade dos poços nesse sistema aqüífero está condicionada à ocorrência desses sedimentos arenosos de subsuperfície, como também pela maior espessura do pacote sedimentar e pelas estruturações da rocha.

A ocorrência de diabásios situa-se na porção central da área de estudo ao longo de uma faixa de direção $\mathrm{NW}$; a produtividade de poços tubulares está condicionada aos fraturamentos da rocha.

Nos poços mistos, a maior produtividade se encontra na combinação dos sistemas aqüíferos Itararé/Diabásio. A espacialização dos valores de capacidade específica revelou tendências bem distintas, onde as áreas de menor potencial se encontram próximas ao contato do embasamento cristalino e as de maior potencial, em faixas de direção NE, ao longo da região de estudo.

A produtividade dos poços na Região Metropolitana de Campinas está relacionada, também, às movimentações neotectônicas dos blocos estruturais definidos na área. A tendência de maior produtividade dos poços nos locais de caimento dos blocos estruturais é notória, exemplificando com os blocos Mumbuca, Itu, Jaguariúna e Americana. Nesse último bloco, há dois comportamentos distintos de produtividade, cuja delimitação entre estas duas graduações é um lineamento de drenagem que corta esse bloco estrutural e se prolonga até o Bloco Pirapitingui.

\section{AGRADECIMENTOS}

Os autores agradecem à Seção de Hidrogeologia do Instituto Geológico, especialmente aos pesquisadores Geraldo Hideo Oda e Luciana Martin Rodrigues Ferreira e ao Departamento de Geologia Econômica e Hidrogeologia do Instituto de Geociências/USP, à CAPES e ao CNPq.

\section{REFERÊNCIAS BIBLIOGRÁFICAS}

BASEI, M.A.S., CAMPOS NETO, M.C., BERGMANN, M. \& FIGUEIREDO, M.C.H. 1986. Geologia da Folha Amparo, 1:50.000. Rel. Pró-Minério/USP. 109 p. Inédito.

BERTACHINI, A.C. 1987. Estudo das características hidrogeológicas dos terrenos cristalinos sob clima úmido, na região de Jundiaí, em São Paulo. São
Paulo. 120p. (Dissertação de Mestrado IGc-USP)

CAMPOS, H.C.N. 1993. Caracterização e cartografia das Províncias Hidrogeoquímicas do Estado de São Paulo. São Paulo, SP. 177p. (Tese de Doutorado IGc/USP). Inédita.

CAVALCANTE, I.N. 1990. Estudos hidrogeológicos de terreno cristalino com 
manto de intemperismo - área piloto de Atibaia (SP). 123p. (Dissertação de Mestrado IGc/USP)

CLARK, D. Programa para tratamento de dados e interpretação de ensaios de bombeamento e de produção (modificado por IPT, BOMBTEST 1.0), São Paulo.

COMPANHIA DE PESQUISA DE RECURSOS MINERAIS (CPRM). 1974. Projeto Sudeste do Estado de São Paulo. Mapa Geológico. Folha SF 23-Y-C. Escala 1:250.000. 1 mapa.

DEPARTAMENTO DE ÁGUAS E ENERGIA ELÉTRICA (DAEE); INSTITUTO DE GEOCIÊNCIAS E CIÊNCIAS EXATAS DO CAMPUS DA UNIVERSIDADE DE RIO CLARO (IGCE-UNESP). 1982. Mapa Geológico do Estado de São Paulo. Folha Campinas. Escala 1:250.000. 1 mapa.

DEPARTAMENTO DE ÁGUAS E ENERGIA ELÉTRICA (DAEE). 1981. Estudo de águas subterrâneas, Região Administrativa 5 (Campinas), SP. São Paulo, SP. DAEE, $2 \mathrm{v}$.

DINIZ, H.N. 1990. Estudo hidrogeológico do Subgrupo Itararé no médio rio Tietê, Municipio de Tietê, SP. $118 \mathrm{p}$. (Dissertação de Mestrado IGc-USP)

DIOGO, A., BERTACHINI, A.C., CAMPOS, H.C.N.S. \& ROSA, R.B.G.S. 1984. Estudo preliminar das características hidráulicas e hidroquímicas do Grupo Tubarão no Estado de São Paulo. In: SIMPÓSIO REGIONAL DE GEOLOGIA, 3., Atas. São Paulo: SBG/SP, p. 359-364.

EMPRESA METROPOLITANA DE PLANEJAMENTO DA GRANDE SÃO PAULO S/A (EMPLASA). 1993. Cenário Regional, Região de Campinas, Área de Metropolização - Aspectos FísicoAmbientais e Sociais. Relatório Técnico EMPLASA, v. 1, 199p.

GROUNDWATER-HIDROGEOLOGIA E ENGENHARIA S/C LTDA. 1984. Estudo de avaliação de recursos hídricos subterrâneos no Municipio de Sumaré SP. Relatório Técnico GW-105/84, 2 v.
INSTITUTO GEOLÓGICO (IG-SMA). 1993. Subsídios do meio físico-geológico ao planejamento do municipio de Campinas $(S P)$. Relatório Técnico IG, $3 \mathrm{v}$.

INSTITUTO GEOLÓGICO (IG-SMA). 1995. Subsídios para o planejamento regional e urbano do meio fisico na porção média da Bacia do Rio Piracicaba, SP. São Paulo. Relatório Técnico IG, $4 \mathrm{v}$.

INSTITUTO DE PESQUISAS TECNOLÓGICAS (IPT). 1981. Mapa Geomorfológico do Estado de São Paulo. Escala 1:500.000, 2v.

LOPES, M.F.C. 1984. Água subterrânea no Estado de São Paulo - Síntése das condições de ocorrência: In: CONGRESSO BRASILEIRO DE ÁGUAS SUBTERRÂNEAS, 3., Anais... Fortaleza: ABAS, v. 2, p. 305-317.

LOPES, M.F.C. 1994. Condições de ocorrência de água subterrânea nas bacias dos rios Piracicaba e Capivari. 83p. (Dissertação de Mestrado Fac. Eng. Civil/(UNICAMP)

PIRES NETO, A.G. 1996. Estudo Morfotectônico das Bacias Hidrográficas dos Rios Piracicaba, Capivari, Jundiaí e Areas adjacentes no Planalto Atlântico e Depressão Periférica Proj. CNPq 150011/94-6, realizado em IGCE-UNESP, Rio Claro, 71p.

SOUZA FILHO, E.E. 1986. Mapeamento Faciológico do Subgrupo Itararé na Quadrícula de Campinas, $121 \mathrm{p}$. (Dissertação de Mestrado IGc/USP)

STEVAUX, J.C., SOUZA FILHO, E.E., TEIXEIRA, J.A. \& LANDIM, P.M.B. 1987. Sistemas Deposicionais do Subgrupo Itararé (Permo-Carbonífero) na Bacia Hidrográfica do Baixo Rio Capivari (SP): um modelo para prospecção de água subterrânea. In: SIMPÓSIO REGIONAL DE GEOLOGIA 6., Atas. Rio Claro: SBG/SP, v.1, p. 355-364.

VLACH, S.R.F. 1993. Geologia e Petrologia dos Granitóides de Morungaba (SP). 414 p. (Tese de Doutorado - IGc/USP). Inédita. 